\title{
The Study on the Pricing Model of the Urban Sewage Treatment Plant Public Private Partnership Project
}

\author{
Jingning Yan \\ Civil Engineering and Architecture School of Nanchang Hangkong University,Nanchang,Jiangxi, \\ 330063, China
}

2248602417@qq.com

Keywords: Pricing model; Urban sewage treatment plant; Public private partnerships; The influence factors; The theory of goal programming

\begin{abstract}
The public private partnership mode is the main financing mode of the urban sewage treatment plant project. Pricing is the key of public private partnership mode. The structure chart of the main participants of urban sewage treatment plant PPP project is established.The main participants of urban sewage treatment plant PPP project include government, the government's investment institutions, private investor institution, project company, contractor, project operator, product buyer, financial institution and insurance company. The concession theory of the public project, the theory of public goods and the regulation theory of public project constitute the theoretical foundation of the urban sewage treatment plant PPP project concession. The influence factors on the pricing of the urban sewage treatment plant PPP project include urban sewage treatment plant construction costs, sewage treatment charges,etc. Based on the theory of goal programming, the pricing goal programming model of the urban sewage treatment plant PPP project is established.In the end the paper puts forward suggestions for the pricing of urban sewage treatment plant PPP project.
\end{abstract}

\section{Introduction}

Government and social capital cooperation mode, referred to as the public private partnership PPP mode. Its abbreviation is the PPP mode.The PPP mode refers to the public sector through the establishment of partnerships and the private sector to provide a way of public products and services. Partners to share not only their own assets and technology, but also to share the risk in the process of cooperation, reasonable distribution of profits. The PPP's partnership contract is signed by both parties. The party a contract usually is government agencies such as the public sector. And sign a contract with the public sector of the party can be a project company, also can be composed of multiple company joint project company, collectively known as the concessionaire of PPP project. [1]

The ministry of finance of the People's Republic of China issued a series of files in 2015.Encouragement in energy, transportation, water conservancy, environmental protection, municipal engineering, low-income housing, health care, education, culture and other public services, cooperation mode is widely adopted by the government and social capital. In view of the need to implement a concession of the energy, transportation, water conservancy, environmental protection, municipal engineering and other specific infrastructure, according to the infrastructure and public utilities concession management method.

As the important infrastructure of the city, the PPP pattern applies to urban sewage treatment plant. The operation mode of the urban sewage treatment plant PPP project is as follows. Sewage treatment aptitude of private investor institution through a concession agreement with the government, and with a concession of the sewage treatment projects. In the charter period, investors through operating the project company, sewage treatment fee and get the appropriate return on investment. When this contract expires, the sewage treatment project is handed over to the government free of charge. The application of PPP mode in urban sewage treatment plant, which can effectively absorb the social capital to invest in infrastructure construction, reduce the government's fiscal pressure, the government will be more money to solve the problem of the people's livelihood. [2]The concession 
agreement of urban sewage treatment plant PPP project usually focus on the pricing problem of concession.

Concession pricing problem is that the PPP model in urban sewage treatment plant project was one of the key factors for successful application. Concession price is related to the rationality of the government public sector and private sector the degree of risk sharing and profit distribution mechanism, it is also related to the benefit of users and unbearable. Therefore, reasonable price concessions urban sewage treatment plants can effectively guarantee the PPP project carried out smoothly during the charter period. The rationality of the urban sewage treatment plant PPP project price concessions, can ensure that a wide range of social benefits and the level of reasonable profit and municipal sewage treatment plant in urban sewage treatment plants to achieve sustainable and healthy development.

\section{The Main Participants of the Urban Sewage Treatment Plant PPP Project}

Based on the special properties of the urban sewage treatment plant construction and operation, this paper established the structure chart of the main participants of urban sewage treatment plant PPP project. [3] The structure chart is Fig. 1.

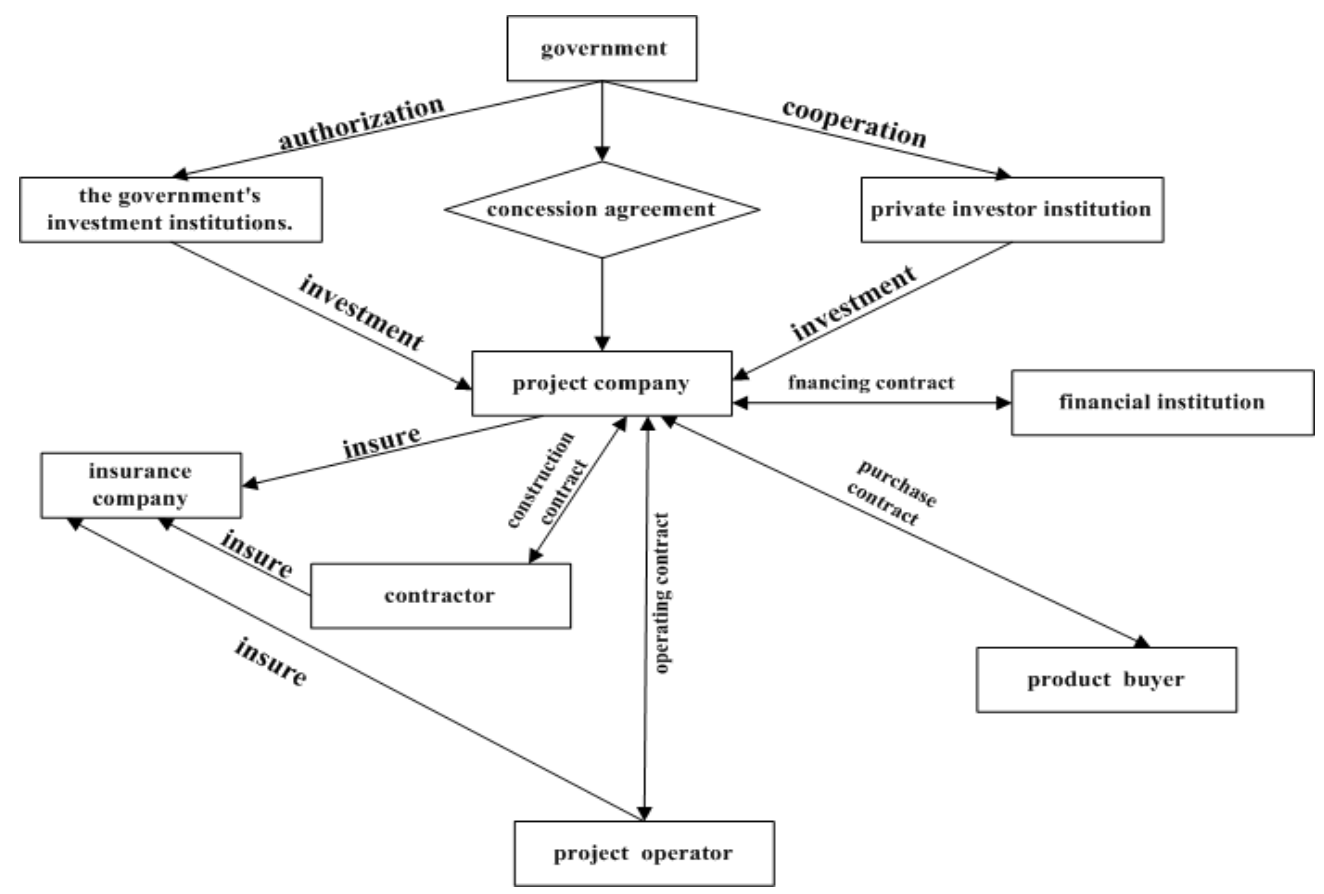

Figure 1. The structure chart of the main participants of urban sewage treatment plant PPP project

Government. As the main control body of the PPP project, the government is quasi profit-making public product managers and project concession rights granted to party. After the PPP project is approved by the government, public bidding and bid evaluation, and the concession rights granted to the project company. Overall, the government determines whether the public product project project, whether to the PPP mode of financing mode, whether through the project examination and approval.

The Government's Investment Institutions. It includes the government's investment companies, state-owned enterprises, etc. Authorized as the representative of the government investment in it as a shareholder and a private equity investment institutions signed agreement established the project company.

Private Investor Institution. Private investment institutions tends to be one of the PPP project sponsors, and on behalf of the government investment institutions establish PPP project cooperation company, investment of capital formation of the company's equity capital. Government departments 
often choose technology, capital, credit and other comprehensive strength of private enterprises or foreign enterprises through open tender.

Project Company. The project company is the company which is specifically set up for the construction and operation of urban sewage treatment plant. On behalf of the government's equity investment institutions and private investment institutions into the capital formation of the company's equity capital. It is the executive main body of urban sewage treatment plant PPP project. [4,5]

Contractor. The contractor is usually a project company's shareholders. This guarantees that the contractor can be a main contractor of the project. If the project company shareholders do not include the contractor, will determine the contractor in the form of tender. The contractor is responsible for the contract signed with the project company by construction project construction.

Project Operator. Project operator in charge of facilities operation management, it is usually with the project company conclude a contract for the wastewater treatment of operation management.

Product Buyer. After the completion of the urban sewage treatment plant PPP project,it should have long-term products buyer prior to the construction of the project company in the project, the project company should signed a long-term purchase contract with product buyer. [6]

Financial Institution. It is mainly to provide loans for urban sewage treatment plant PPP projects, including the international syndicated, commercial Banks and investment trusts, etc. If the PPP project investment is particularly large, it needs of several financial institutions, syndicated to provide loans.

Insurance Company. As the big funds, long project cycle, participants, is faced with many unpredictable various risk factors. Is necessary for the project participants to identify the future risk and insurance in time. The insurance company can share the project risk.It can offer insurance for the project's risk.

\section{The Theoretical Foundation of the Urban Sewage Treatment Plant PPP Project Concession}

The Concession Theory of the Public Project. The government within the prescribed time limit, through the way of the licensing, the supposed to be controlled by its nature of public utilities project implementation, to private enterprise for development and management of the maintenance management.

The Theory of Public Goods. Public goods is the product of the utility extension in the cost of others is zero, and therefore could not exclude others to enjoy it, this makes the public goods to the public, but let suppliers unprofitable. Public goods can't like ordinary commodity solution by the market, but to be provided by the non-market mechanism. The government also need to produce due to the public, it is mainly to provide for the organization and implement of public goods.

The Regulation Theory of Public Project. The marketization of public utilities is not equal to the cancellation of the government's rules and regulations. The government still need to make sure that society as a whole benefits from damage, and maximize utility project economic efficiency. Control department according to the regulated enterprises submitted to regularly review to list the cost of capital and operating costs for pricing service. Public project regulation theory including incentive regulation, concession bidding regulation and price cap regulation. [7]

\section{The Influence Factors on the Pricing of the Urban Sewage Treatment Plant PPP Project}

Urban Sewage Treatment Plant Construction Costs. Construction cost estimating is usually carried out after detailed feasibility study. Because the basis of reasonably complete data, can improve the estimation accuracy.This needs to be estimated respectively building engineering, installation engineering, equipment and instruments purchase expense and other cost project cost. Calculate according to the corresponding estimation method, basic reserve funds, the price of reserve funds, loan interest, construction cycle finally combination form construction cost data.Construction project cost belongs to the early fixed expenses. 
Urban Sewage Treatment Plant Operating Costs. During the operation of urban sewage treatment plant, operating costs include fuel fee, daily management, and expenditure on power and agents, sludge disposal charge, staff salary welfare and daily maintenance etc. The characteristics of urban sewage treatment plant PPP project is operating time is long, and facility maintenance projects need corresponding funds to continue operating. So it has to do with the company's management level, technical standards, personnel ability has a great relevance.

Sewage Treatment Charges. Sewage treatment chargesl is related to the project company operating income. [8]In the franchising period, sewage treatment charges is a relatively fixed.In inflation, sewage treatment, of course, too much or too little, and so on and so forth, have corresponding adjustment mechanism, in order to balance the project company and the government's income.

The Concession Period. Project concession period is generally composed of construction period and operation period. In concession project construction period is regarded as the decisive factor, because in the concession period given conditions, investors to shorten the construction period, can get a longer operating time. Good control during construction, some risks may be transformed into can be controlled and even beneficial opportunities. Therefore, the public sector pricing will estimate the construction period of a more appropriate time. To determine the term of concession is an important issue in concession agreements, the longer the period, the longer back project investment, will be conducive to the project company will pays quickly. Therefore, the PPP project of concession agreement shall determine the appropriate concession operation as far as possible.

Sewage Treatment Capacity. Price under the condition of relatively fixed in sewage treatment, sewage treatment capacity, how many will determine whether the project of the company's cash flow, is the foundation of the cash inflows and cash outflows. In the project charter operation period, if the project company's sewage treatment capacity can not reach the specified value in the concession agreement, the government for financial subsidies.

Project Risk Sharing and Benefit Compensation Mechanism. The construction cycle on urban sewage treatment plant PPP project is long, and its investment is large. Involving government, private companies, contractors, financial institutions, insurance companies, products buyers, and many other participants in the complex contractual relationship between the parties, the general engineering project risk factors also more. [9]Correctly identify the project risk factors, the reasonable share the corresponding risk, offer fair compensation for risk bearing side is the key to the success of the urban sewage treatment plant PPP project.

The Return on Investment. The return on investment should be higher than bank loan interest rates for a long time. The determination of reasonable rate of return on investment is advantageous to the urban sewage treatment plant the PPP project successful implementation, on the one hand can encourage the enthusiasm of investors, without company obtain sudden huge profits of the project: on the other hand can guarantee the fairness, to some extent, the sustainable development of the sewage treatment industry.

\section{The Establishment of the Pricing Model of the Urban Sewage Treatment Plant PPP Project}

The Theory of Goal Programming. Different targets in the theory of goal programming is to put the system on the basis of the importance of sorting, first consider the most important goals, then consider secondary targets, and so on, the goal is divided into different levels, at all levels at the same time the goal is to minimize the expected aim, and the deviation between the actual. [10]Objective function is according to the positive and negative deviation of various objective constraint variables and gives the corresponding priority factor to construct, as each target is determined, to a narrow deviated from the target.

The Pricing Goal Programming Model of the Urban Sewage Treatment Plant PPP Project. Goal programming principle of pricing is proposed, which can consider the interests of the enterprises 
and consumers tripartite target, achieve relatively consistent pricing. The pricing goal programming model of the urban sewage treatment plant PPP project is Eq.1, Eq.2, Eq.3.

$$
\begin{aligned}
& \min Z=A_{1} Q-C+\left(A_{0}-A\right) Q \\
& A \leq A_{1} \leq A_{0} \\
& A Q+D=A_{0} Q
\end{aligned}
$$

$A_{1}$ represents the price of project operator. $A_{0}$ represents the cap on the price paid. A represents the price of the willing.D represents the government subsidy.C represents the cost.Q represents the sewage treatment capacity.

\section{Summary}

The general principle of the urban sewage treatment plant PPP project pricing is to ensure that the infrastructure project smooth implementation at the same time, to ensure that the social capital investment returns. Do business, government, user tripartite win-win situation. Based on the study, puts forward suggestions for urban sewage treatment plant PPP project pricing is as follows: establish a reasonable regime of the urban sewage treatment plant PPP project; formulate relevant laws on the urban sewage treatment plant PPP project; perfect the project risk sharing and benefit compensation mechanism.

\section{References}

[1] D.Q.Chen,S.S.Zheng:Construction Economy,Vol.7 (2011) No.4, p.12.

[2] Z.T.Ren and S.X.Gao: Price Theory and Practice,Vol.2 (2015) No.5, p.51.

[3] H.Zhang,Z.F.Wang and J.Y.Ding: Journal of Engineering Management, Vol.29 (2015) No.2, p.71.

[4] W.Liang and S.Q.Wang: Journal of Engineering Management, Vol.26 (2012) No.4, p.23.

[5] Y.B. Su,J.Ma and M.D.Li: Sichuan Building Materials, Vol.39(2013) No.1, p.246.

[6] W.X.Wang: Product Pricing of Urban Transportation Infrastructure Projects Under PPP Pattern ( Publishing House of Southeast University, China, 2013).

[7] G.Q.Zhou and X.W.Zheng:China Transportation Revies, Vol.37 (2015) No.9, p.64.

[8] L.Hu:Study on Risk Control of City Infrastructure Finacing Based on Public-Private-Partnerships( Chongqing University Press, China, 2013).

[9] C.Li and S.B.Zhang:Urban Rapid Rail Transit, Vol.27 (2014) No.2, p.72.

[10] J.Guo:Management Review, Vol.25 (2013) No.7, p.11. 